\title{
Xylella fastidiosa and the Olive Oil Crisis in Puglia
}

no one can travel through Puglia, the heel of Italy's boot, and not be struck by the seemingly endless groves of olive trees that start north of Bari and extend for hundreds of kilometers to the farthest tip of the Salento peninsula. Olives have defined Puglia for centuries, culturally, socially, and economically. Indeed, it is hard to imagine the Puglian countryside without those stately groves, some with monumental gnarled trunks that date back to the thirteenth century when Holy Roman Emperor Frederick II built the majestic Castel del Monte, which still looks out over the olive groves of northern Puglia. And yet today, those trees, and so Puglian culture and agriculture, face an existential threat in the shape of Xylella fastidiosa, a bacterium carried by the otherwise innocuous spittlebug that is wreaking destruction on the olive groves of southern Puglia while gradually spreading northward. Those historic groves may have to be replaced wholesale with different, more resistant cultivars, or indeed olive growing may be abandoned in large parts of the region altogether. If that comes to pass, it will constitute not just an agricultural shift but a drastic conversion of the Puglian economy, checking the remarkable progress that has been made in Puglian oil production over the past few decades. During spring 2019, I spent a month traveling through Puglia interviewing olive growers and olive oil producers to learn about both the recent history of Puglian oil and how growers are reacting to the Xylella blight and its diffusion. They expressed by turns optimism, enthusiasm, pride, concern, anger, and desperation.

Puglia, one of Italy's twenty regions, stretches nearly 400 kilometers along a northwest to southeast axis (Figures 1 and 2). It is mostly low-lying and agricultural with a hilly spine running its length. The Adriatic littoral is rocky and dramatic; the Ionian coast mostly sandy. That variation has made the Salento peninsula (Lecce province plus much of Brindisi and Taranto) a major summertime tourist attraction. The region, moreover, is sprinkled with dozens of towns and cities: each boasts its own charming central square and stunning baroque churches constructed of the local white-yellow stone. Puglia is also the leading oilproducing region in Italy, normally accounting for between one-third and one-half of national production. Historically it includes two distinct oil traditions, that of the Salento and that of the nord barese, the region north of Bari. Already in the eighteenth century Puglia dominated world oil production. Oil from the Salento in particular was much in demand as a lubricant for wool manufacture, as lamp oil, and for making soap. At the risk of a pun, Salentine olives oiled the wheels of European industrialization. Locally it was also used as table (or comestible) oil, though mostly by the poor. Meanwhile, in the 1840s, innovations in harvesting and pressing techniques were adopted in the nord barese and led to a revolution in table oil production there; and so, throughout much of the twentieth century, the Salento continued to make low-quality olio lampante (lamp oil) while the nord barese made high-quality table oils that could compete with the best oils from northern Italy and France. The fundamental difference was that olives in the Salento were generally harvested from the ground after they had fallen from the trees, in winter or spring, bruised and overripe, while in the nord barese the olives were harvested directly from the trees in the fall while still fresh.

Whether olio lampante from Lecce or a better-quality table oil from Bari, Puglian oil throughout the post-World War II decades was generally sold in bulk. Central and northern Italian manufacturers, especially from Tuscany and Liguria, bought stronger Puglian oils to blend with other milder ones and sell under well-known brands. Then, starting in the last decade or so of the twentieth century, two important changes occurred in the Puglian oil world. On the technological side, Puglian producers (like producers throughout the world) switched from the millennia-old practice of crushing olives under massive granite wheels and pressing them on fiscoli (stacked woven rush disks on which the olive paste is spread) to a new "continuous" process (developed in Tuscany in 


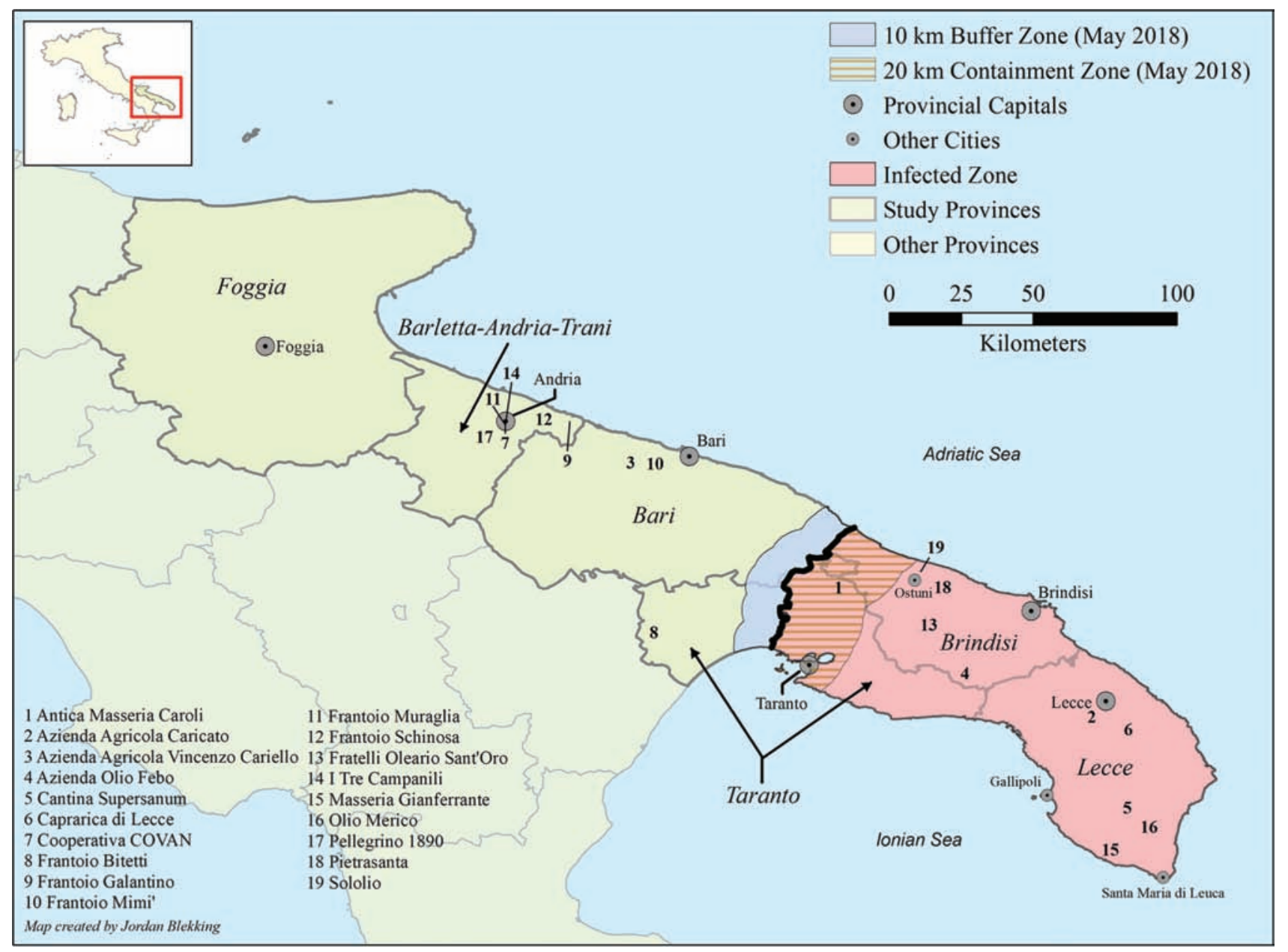

FIGURE 1: Map of Puglia (with a list of producers and others visited).

ILLUSTRATION BY JORDAN BLEKKING (C) 2020

the 196os). The continuous process involves a production line that mechanically washes, mills, "malaxes" (a kneading process that separates oil droplets from the milled paste), centrifuges, and (usually) filters the oil. Among the advantages of the new technology are speed and efficiency. The rate of oil production increased tenfold and more and required fewer workers. With minor dissent (see below), producers also found that quality increased with the continuous process (Figure 3).

With the older, slower process much oil was inevitably made from olives that fermented as they waited to be pressed, however harvested, yielding an inferior oil. The finished oil also turned rancid more easily in the months after production due to oxidation or impurities. As a result, flavors often ranged from slightly sweet to acidic to nutty. Thanks to the continuous process that is not only faster but reduces exposure to harmful oxygen, the past few decades have seen the production of greater quantities of higher-quality extra virgin oils characterized by a fresh fruitiness with distinctly bitter and pungent qualities. To an older generation of Italians, those flavors are still unusual and not always desirable. They are achieved by what are today considered best practices, namely harvesting the olives when they are not fully ripe (in October or November), milling them within 24 hours or less of harvest, keeping the temperature and mixing times in the malaxer low, and good quality filtration. Most of these steps reduce yield, and so quantity must be sacrificed to achieve quality. Meanwhile, the greatest enemy of good-quality oil is oxidation and so the frantoiano (oil maker) seeks to minimize exposure to air during the production process. It is, indeed, a universal frustration among quality producers that no amount of care in processing can prevent the oxidation that takes place if, as often happens, oil is left to languish in opened bottles and tins for months on end by consumers.

The other important recent development in Puglia is the transition from marketing bulk oil to bottling oil under local Puglian brands. Why sell a high-quality Coratina oil 


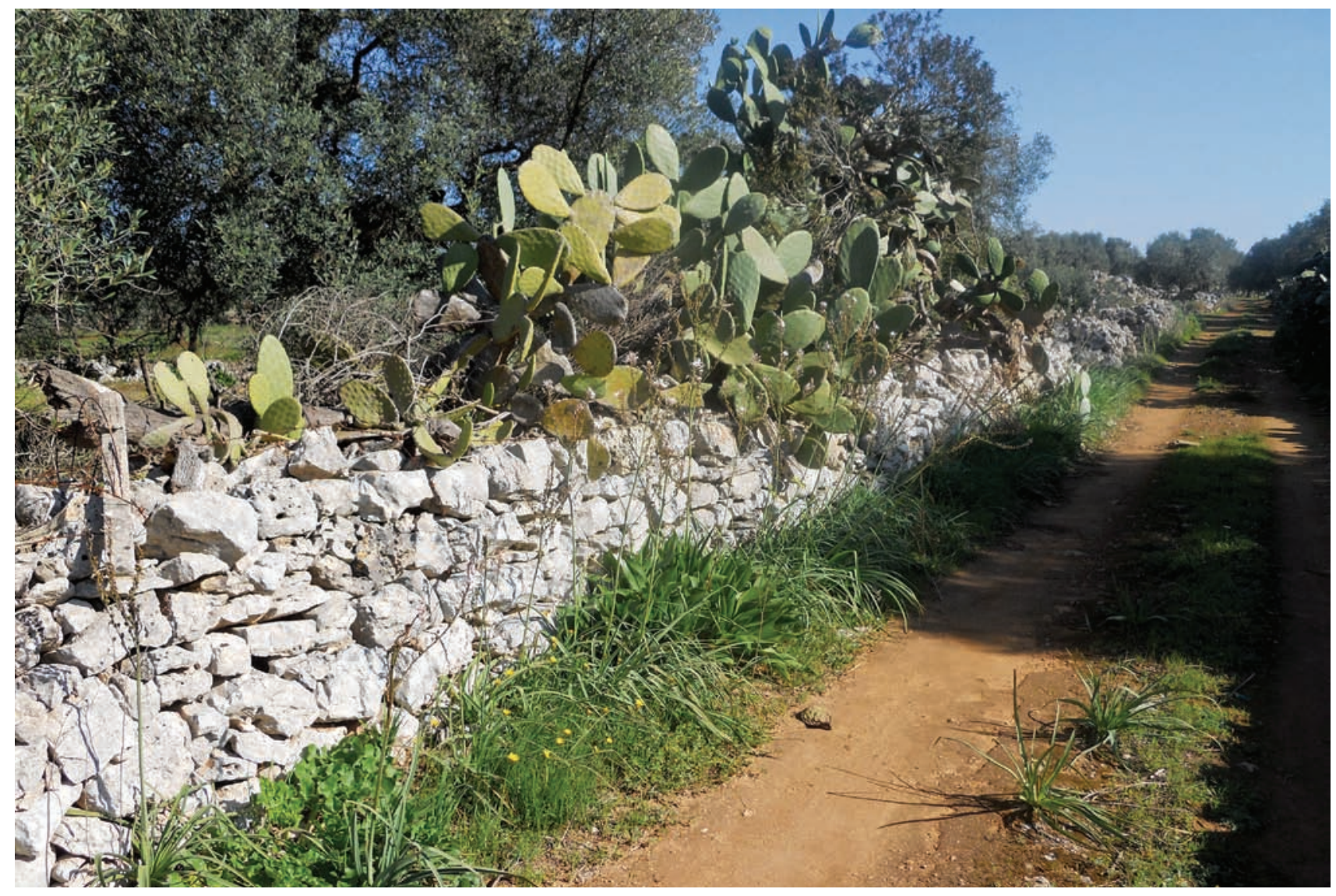

Figure 2: Country lane in Lecce.

PHOTOGRAPH BY CARL IPSEN (C) 2019

(the dominant cultivar of the nord barese) to northern or multinational processors for blending when that oil has its own unique qualities and can compete with the best oils made in Tuscany, Liguria, and elsewhere? Over the past 30-40 years then, Puglia has seen a gradual (and still not complete) transition from traditional to modern harvesting and production techniques. Meanwhile, Puglian oils have ranged from oldstyle olio lampante sold in bulk to some of the best extra virgins in the world bottled with the labels of individual Puglian producers.

It is this evolving and progressively better-valorized world of Puglian oil that in the past few years has been stricken by the Xylella bacteria. As early as 2008 , farmers in the area around the historic Ionian port of Gallipoli noticed that the leaves on some trees, normally evergreen, were drying up and the trees failing to produce fruit. Identified as Olive Quick Decline Syndrome (OQDS), the condition spread alarmingly throughout the Salento and was attributed in 2013 to Xylella fastidiosa, a bacterium carried by spittlebugs. ${ }^{1}$ Although a scourge of grapes, citrus, and other crops in the Western
Hemisphere for over a century, Xylella had never before been detected in Europe. It likely arrived with infected plants shipped from Central America to the Netherlands and then transported, undetected, from there to nurseries in Puglia. Since its outbreak, Xylella has spread throughout the province of Lecce and from there up the peninsula at a rate estimated at $20-25$ kilometers per year. Proposed responses have ranged from clearcutting or uprooting of olive groves to the general adoption of organic "best practices" and have inspired heated debate among farmers and politicians. To date no effective response has been implemented and oil production in the Salento has plummeted. Some argue that continued diffusion is inevitable and that farmers must find a way to live with the disease as it runs its course.

The Xylella map currently includes an "infected" zone, comprising most of the Salentine peninsula, a zo-kilometer containment zone from which it is hoped the bacteria will not spread further northward, and a 1o-kilometer uninfected "buffer" zone that is being carefully monitored. The boundaries for these zones were recently shifted northward in 


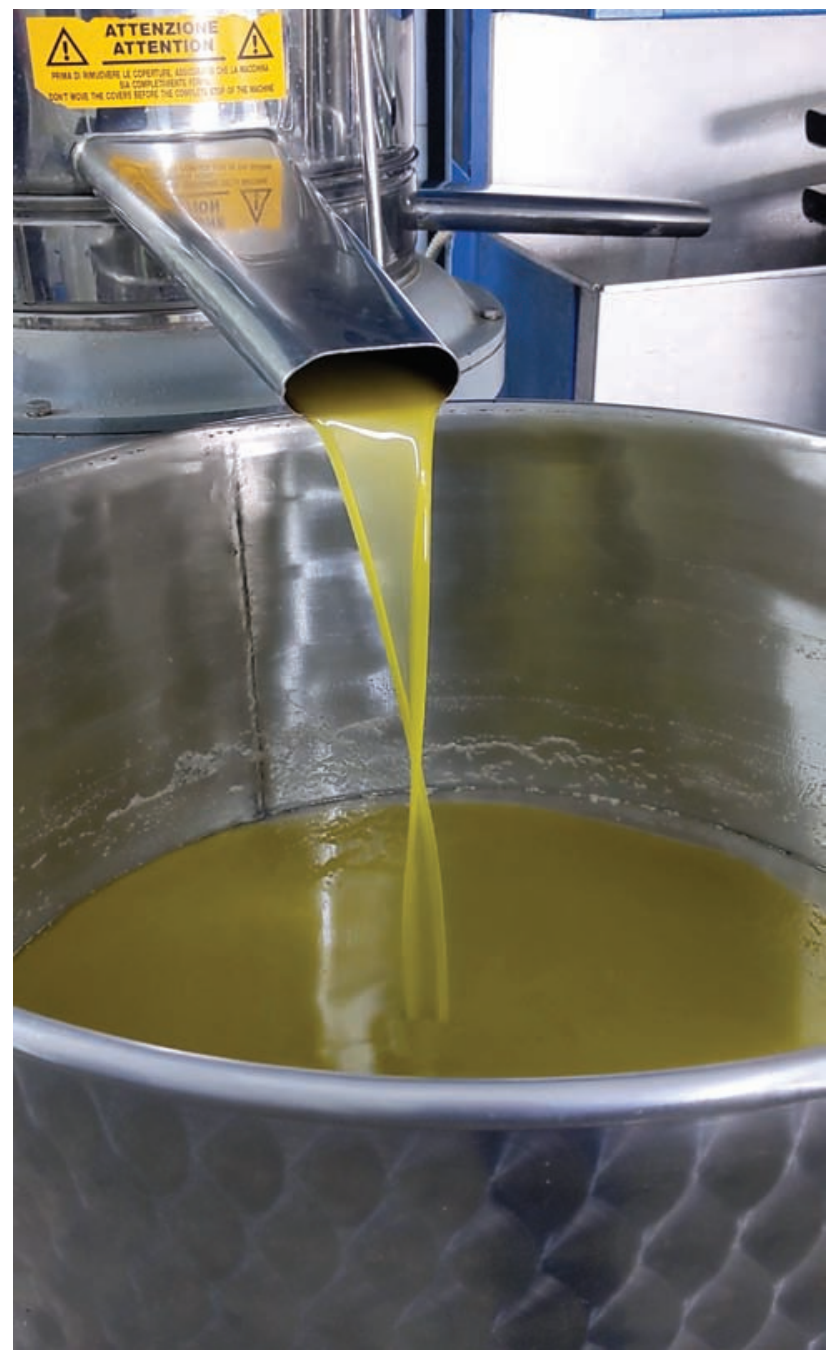

FIgURE 3: Puglian oil from the 2019 harvest.

PHOTOGRAPH BY MiCHAEL IPSEN $\odot 2019$

tandem with the steady march of the bacteria. At the time of the interviews, the buffer zone, as depicted in Figure 1, crossed the peninsula perpendicular to its main axis in a band from north of the city of Taranto to the southern edge of Bari province; the EU Phytosanitary Commission has more recently decided to narrow the zones to facilitate control (Scagliarini 2019). The initial hope, still entertained, is to confine the infection to its peninsular origin. Yet, Xylella (often in different but previously undetected strains) has by now been identified in at least Spain, France, Israel, and other Italian regions. ${ }^{2}$ In some manner or other, living with Xylella may be the only option.

Some argue that traditional practices in the Salento have contributed to the progress of the infection. Trees there are typically pruned infrequently, and rather than mowing or plowing, the region has seen heavy use of herbicides over the past half century. That practice leaves the soil free of grass, which facilitates the traditional harvesting of fallen olives off the ground but also robs the trees of organic matter in the soil, leaving them more vulnerable to infection. To make matters worse, as costs have risen and prices stagnated in recent decades many smallholders have simply abandoned their groves. Poorly cared for and malnourished trees may indeed have provided fertile ground for Xylella to flourish.

To fight the spittlebug, obligatory mowing and pesticide applications have been decreed in the buffer and containment zones, though neither property owners nor local administrators have been universally compliant. The initial response in 2015 included an order for the eradication of all infected trees and also all trees within 100 meters of the infected ones. There followed a long and complicated story of accusations, counter-accusations, conflicts, protests, lawsuits, and criminal charges that involved farmers, scientists, police forces, environmentalists, and politicians both local and national. Suffice it to say, the original plan was not implemented, although significant numbers of trees have been uprooted, both as a preventive measure and to clear land of scorched and unproductive trees for new plantings (Figure 4). Many claim that if the original plan had been carried out, Xylella could have been stoppedwe shall never know-while others argue that the plan never had any hope of success (Strona et al. 2017). Eradication as a preventive measure is complicated by the fact that trees can harbor the bacteria for months or years before showing any symptoms of infection. According to a February 2019 study there are now more than 4 million scorched and unproductive trees occupying 50,000 hectares, mostly in Lecce province, and accounting for about 10 percent of Italy's oil-producing capacity (Italia olivicola 2019). Unfortunately, those numbers are destined to increase.

In the pages that follow, I trace my springtime voyage in Puglia, from the as yet uninfected areas in the north-the nord barese and western Taranto-to the containment zone in Brindisi province to the infected zone in the Salento. The history and commercial-technological changes described above are the essential background to understanding the challenges faced by farmers and oil producers.

\section{Uninfected: The Nord Barese}

Unlike the picturesque towns dotting the nearby Adriatic coast, Andria, situated 55 kilometers north of Bari, has the workaday feel that characterizes many of Italy's nontouristic cities, defined more by present-day economic activity than its artistic heritage (although Andria does have a charming historic center). And in fact, no city better embodies the oil tradition of the nord 


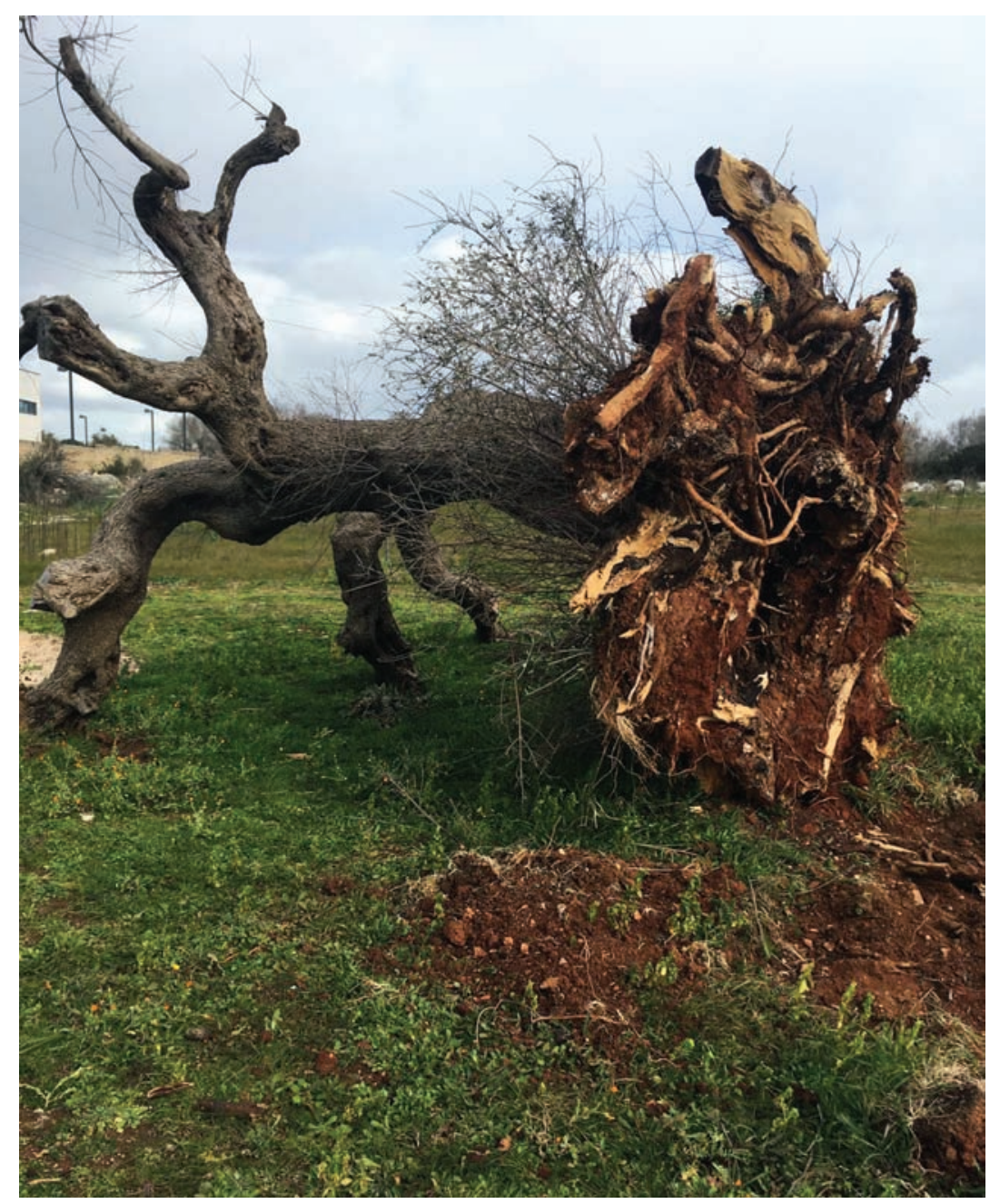

FIGURE 4: Uprooted olive tree.

PHOTOGRAPH BY MARTA CESI $\odot 2019$

barese, Puglia's most important oil region, than Andria. In the 1970s, before the introduction of continuous-cycle mills, the city boasted over 120 frantoi (olive oil mills) in a city of under 100,000 inhabitants. Today there are just over a dozen and only one of these uses the traditional stone crusher, mats (fiscoli, now of synthetic fiber), and hydraulic presses. Meanwhile, even though the number of frantoi is much smaller, production over the past 50 years or so has increased significantly (nationwide by a factor of about two). Doing a back-of-the-envelope calculation, then, a modern continuous-cycle production line in Andria is processing 10-20 times that of a traditional frantoio half a century ago. According to one producer I interviewed, Andria alone (a comune of 400 square kilometers) accounts for 15 percent of national production. Coratina is the dominant cultivar there, which likely produces the strongest olive oil in the world with polyphenol levels 3-4 times that of most other oils.
Some find Coratina overpowering; others - most of the andriesi I met, for example-think it the king of oils. For now, Andria lies beyond the reach of the Xylella blight.

Giuseppe Leonetti and his son Francesco are up every morning at four to head out to their olive groves outside Andria (Figure 5). I would venture to say that one can learn more about olive growing by spending a few hours among the trees with Giuseppe and Francesco than most any other way: the annual cycle of budding, flowering, fruit maturation, and harvesting; the rhythms and techniques of pruning and fertilization; the telltale signs of the fungi, flies, and moths that threaten the trees and the harvest; and the climate challenges faced at different times of year. Self-described contadini (farmers), these men have a wealth of knowledge that many other growers (and likely even agronomists) would surely envy. They are proud of their trees and lavish care on 


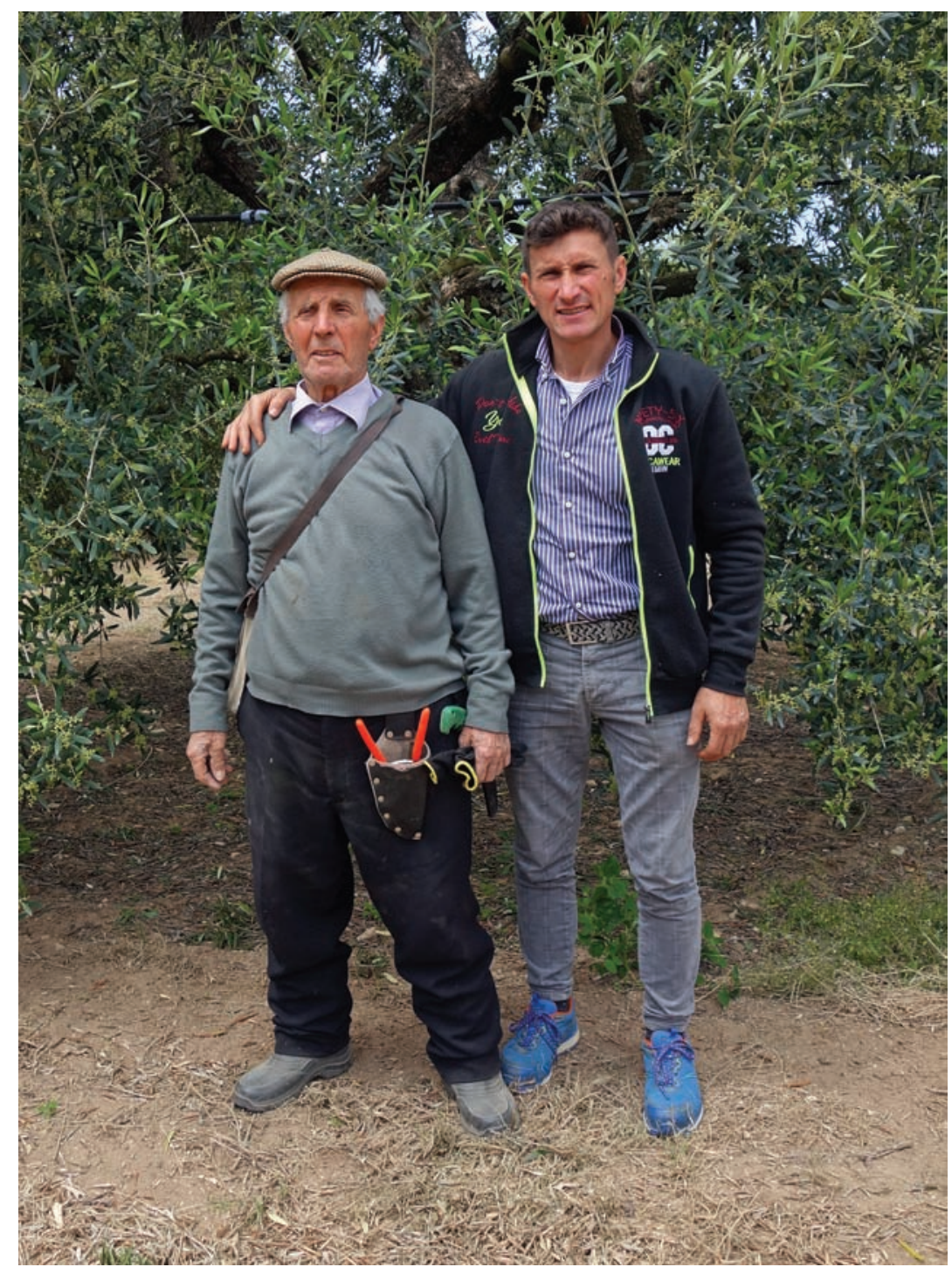

FIgURE 5: Giuseppe and Francesco Leonetti.

PHOTOGRAPH BY CARL IPSEN (C) 2019

them that verges on paternal: annual pruning and constant vigilance for warning signs of olive flies or the "peacock's eye" fungus (spilocaea oleaginea), for example. On a drive through the countryside, Francesco quickly identifies groves tended by expert pruners like himself and those instead hacked at by less skilled farmers, a shortcoming that will seriously compromise the harvest, at least in a good year.

The year 2018, however, was not a good one in Andria. One winter night in February, temperatures plummeted to $-7^{\circ} \mathrm{C}$ and then over the next couple of days zoomed back up to $20^{\circ} \mathrm{C}$. No one living can ever remember a climate event like this, and it is hard not to view it in the context of global climate change. The effect on the trees was devastating: the harvest was decimated, and in some cases sap literally burst through the trees' bark. Groves near to the sea fared better, while those at higher elevations saw production entirely wiped out. Giuseppe and Francesco's harvest that year was about 10 percent of their normal yield. By comparison, 2019 brought a bumper crop. I was happy to return in November and join them before dawn for a day of harvesting by scuotitore, a machine that grasps the tree trunk and shakes the olives free so that they fall into waiting nets below, and relying on a crew of skilled workers.

Also in Andria, Savino Muraglia represents the fifth generation managing his eponymous family firm. Once surrounded by olive groves his frantoio is now absorbed into the city's urban fabric. Muraglia switched to a continuous-cycle press in 2000 , and in place of the bulk oil of the past, today his oil is all sold in Muraglia bottles and tins. Echoing other producers 
I met, Muraglia noted that Italians, for whom oil is a staple food, are often unwilling to pay for high-quality oil. He finds greater appreciation abroad and exports 70 percent of his production; US specialty importers, for example, are even willing to airfreight his oil in November so that they can get it at its freshest and most pungent, while in nearby Bari he typically encounters complaints that his oil is too spicy. One of Savino's marketing innovations, since adopted also by other producers, is to market his oil in hand-painted, locally produced ceramic jars. These have enjoyed significant success, especially as wedding gifts, and have helped to revive traditional Puglian pottery works.

Savino is also president of the Puglian section of Coldiretti, Italy's National Confederation of Farmers, and so is on the frontline of the fight to contain the spread of Xylella. And while numbers of growers I spoke with in the nord barese ascribed that spread to the relative neglect of groves in the Salento to the south, Muraglia instead warns against assigning too much responsibility to Salentine practices. He does nonetheless share his neighbors' hope that the additional care the nord baresi devote to their groves may provide a degree of protection. As Muraglia points out, for property owners in the infected zone, there is little incentive to care for groves that have dried up and so become unproductive-it looks like throwing good money after bad — and so they ignore the regulations. Thus far the political will (and needed funding) has been lacking to attack in a systematic way this blight that poses a threat to olive production - not only in Italy but throughout Europe. At the current rate of diffusion, Xylella should reach the nord barese in about five years.

\section{Uninfected: Western Taranto}

Rosa Bitetti is an exuberant young woman who emanates authority and good cheer as she shows visitors around the frantoio that she and her brother Mario inherited from their parents and grandparents in the province of Taranto. As a child Rosa recalls local contadini arriving each day during the harvest carrying cloth sacks filled with the day's olives. The sacks were weighed and then placed on the floor with a label identifying their provenance. Over subsequent days, the contadini returned with additional sacks to add to the piles until the harvest was completed and each batch of olives could be crushed and pressed. Rosa and her friends played hide-andseek among the mounds of sacks, breathing in the aroma of fermenting olives. The olives were crushed on a traditional granite crusher and the paste transferred to fiscoli stacked high on the hydraulic presses that squeezed out the oil. That oil was of course not up to present-day standards, but it found both a market and favor as comestible oil among the contadini and local population.

Rosa and Mario's father was the first miller in the area to replace his fiscoli and hydraulic presses with a continuouscycle operation in 1998 (thanks in part to EU funding). The Bitetti farm has always processed both its own olives and those of other growers in the area, and not all of those growers were happy with the changes. In fact, Bitetti lost a number of clients as a result, and to this day the frantoio maintains a stone crusher (but not the fiscoli and presses) for those clients who prefer it. Even with the new mill, Bitetti oil, like most Puglian oil, continued to be sold in bulk. As the years passed, though, the bulk market became less and less profitable; some years Rosa and Mario barely covered their expenses. Fed up with that situation, they began bottling under their own label in 2014 in order to get higher retail prices, and the results have generally been good. Rosa now travels to a series of food fairs throughout Italy looking for buyers; I met her at one of these.

In recent years, Taranto, like the nord barese, has suffered from increasingly unpredictable weather, again likely a function of climate change. Mario remarked that while they used to get one disastrous year every decade or so, the last six years have seen bad years alternate with good ones. In 2018 a mild wet summer favored the olive fly, a perennial foe of olive growers, which resulted in a loss of 70-75 percent of the harvest. Xylella has not yet reached Rosa and Mario's farm, which lies to the west, but it is coming.

\section{The Containment Zone: Ostuni}

Driving southeast from Bari one passes into the buffer and containment zones and arrives at the "white city" of Ostuni. Not far from Ostuni, Raffaele Leobilla and his brother Donatello work their family groves. These consist of classic hundred-, some claim thousand-, year-old Ogliarola trees, historically left more or less untended with olives harvested from the ground for olio lampante. Abandoning a career as a chef in northern Italy, Raffaele returned home to do something new. He and Donatello have adopted organic practices; they also prune the trees every two years and harvest the olives very early, starting in the first week of October and using automated rakes that dislodge the olives (the trunks are too large for the shakers typically used). They process and bottle their Pietra Santa oil at a high-quality frantoio in Ostuni. In recognition of their efforts with these ancient trees, their oil has been recognized by the local Slow Food Presidium. Asked whether he contemplates building his own frantoio, Raffaele replies that with Xylella at the doorstep - and Ogliarola is the cultivar 
that has suffered the most-he has put that dream aside for now. Meanwhile, regarding the long grass growing in the untended grove next to his, he concedes that the mowing regulations have in fact been largely unenforced.

I visited with two other growers/producers in the north end of the "infected" zone (see Figure 1) who provide a study in contrasts. Aldo Sant'Oro is the young scion of a family that has been raising olives near San Michele Salentino for three generations. In 1994, a couple of years after Aldo's birth, the family built a continuous-cycle frantoio and began concentrating on producing high-quality oil. The effort has paid off: their oils have won significant prizes and captured markets in Japan and Germany. In recent years Sant'Oro also began conversion to organic practices, and while most of the growers in the area apply heavy doses of herbicide, Aldo's family plows their groves several times a year to reintegrate the organic matter into the soil. They battle the olive fly by carefully monitoring adhesive traps, and as soon as they see a few flies in those traps they apply an insecticide approved for organic regimes. Aldo betrays a confidence that may be a function of his youth: although Xylella is literally at his doorstep he assures us that his trees are healthy and will prove resistant to the disease. That confidence doubtless owes something to past success. While the 2018 harvest was pretty much a disaster throughout the region, whether because of the freeze farther north or the olive fly in the Salento and Taranto, Sant'Oro fared better than most. They harvested early in October, at times working around the clock, and brought in about 50 percent of their normal yield-the highest figure I heard anyone report for that year-before suffering from the olive fly infestation that devasted other nearby growers.

About 30 kilometers south of the Sant'Oro frantoio, Chiara Paladini and her mother produce Olio Febo near Erchie. The property has been in their family for centuries, although following a familiar storyline the past few generations have not paid a lot of attention to the groves as family members have tended to pursue professional careers (as does Chiara herself). The Paladini trees are primarily Ogliarola and Cellina di Nardò, the principal cultivars of the Salento. They market via direct sale and mostly online, especially to Germany. Like Sant'Oro, Olio Febo has almost completed the transition to organic. In contrast, however, although the massive Paladini trees appear to be healthy, Chiara is seriously concerned about the arrival of Xylella. As a preventive measure she has pruned a number of the ancient trees down to trunks of a couple of meters height and has grafted on Leccino, a cultivar held to be more Xylella-resistant (Figure 6). ${ }^{3}$ As we explore below, this is one of a number of strategies adopted in response to the disease.

\section{Infection: Lecce and the Salento}

Continuing another 40 kilometers to the southeast, and so deeper into the infected zone, one arrives in Lecce, historic capital of the Salento (some call it the Florence of the South). Francesco Caricato lives there and farms 15,000 trees in nearby San Pietro in Lama, where his ancestor first established a frantoio in 1815. Caricato is something of an iconoclast. To begin with, he runs two frantoi- one continuous cycle and one traditional with crushing wheels, fiscoli, and a hydraulic press - and maintains that the latter makes better oil. According to his analysis, compared to high-speed modern mills, the traditional granite wheels gently accomplish both crushing and malaxing at lower temperatures, although he concedes that oxidation is a negative factor. Caricato makes a rare affiorato (which literally means "skimmed") oil. Affiorato is largely a lost art: the crushed olives are transferred to a vat where the water and paste naturally sink and the oil rises. That oil skimmed off the top is the affiorato, a small percentage of the total yield. It is his premium oil and gets a good price (for example at Buon Italia in Manhattan's Chelsea Market). The remaining paste is transferred to fiscoli and pressed. As an aside, it is from affiorato that we get the idea of virgin oil, virgin insofar as it has never been pressed. Caricato's traditional press is very slow, and he processes 10-12 times as many olives per shift on his continuous-cycle mill (consistent with our calculation above for Andria). In a good year, he will harvest and press from October until January or February (mostly continuous cycle). As the season progresses he gets a lighter, sweeter oil that is higher yielding but lower in value.

Caricato has also long experimented with different cultivars, and his groves include significant plantings of Cornulara, a local olive virtually abandoned by other growers, Leccio del Corno, and Leccino. That experiment has paid dividends as these cultivars are proving more resistant to Xylella. Indeed he guesses that pretty much all of his trees test positive for Xylella, yet remain productive. His primary response has been micro-pruning, frequent mowing - the soil is too rocky to allow plowing - and the continued application of compost made from the sansa (the olive residue left after pressing or centrifuging) combined with vegetable cuttings. He is also progressively grafting Leccino and Frantoio, both Tuscan cultivars, onto his ancient trees in hopes of preserving his rootstock. Caricato argues that it is a good thing that the initial order to clear-cut around infected trees was not implemented. If it had been, aside from ruining his business, he would not have been able to observe and select those trees that are proving more resistant. And while his grove is not as florid as it was a decade ago, it is 


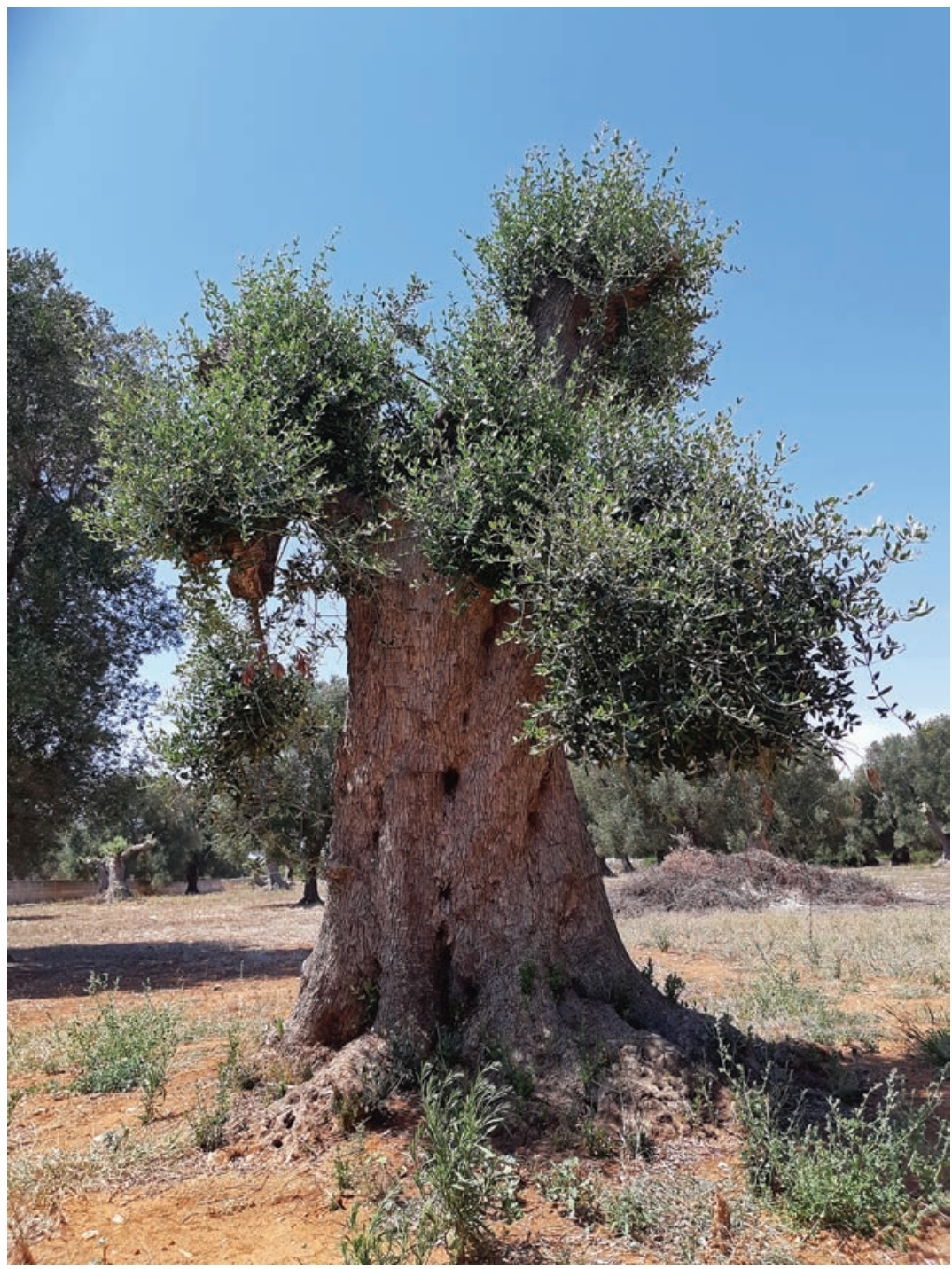

Figure 6: Grafted trees of Olio Febo.

PHOTOGRAPH BY CHIARA PALADINI (C) 2019

certainly green, and signs suggested that the coming harvest would be a good one (as it indeed proved to be).

Traveling a mere 15 kilometers from Caricato's groves one arrives at a very different scene in the comune of Caprarica di Lecce. Paolo Greco is the town's mayor and also the Puglian representative for the Associazione Nazionale Città dell'Olio (National Association of Oil Cities). Fully 95 percent of tiny Caprarica (about 11 square kilometers) consists of olive groves. Since World War II, local production has been dominated by a handful of families who operate the town's five frantoi, while over the past 20 years, Caprarica has moved from producing 100 percent olio lampante to bottling extra virgin oil under a number of different labels, parallel to changes elsewhere in Puglia. In these past few years, however, their world has been hit by, as Greco describes it, il terramoto (the earthquake) that is Xylella. We toured the countryside surrounding the small town and it was hard to find groves that were not affected: scorched trees filled the landscape.

According to Greco, a couple of years ago growers held out the hope that they might weather the storm. Now instead, they have with near unanimity concluded that little or nothing can be done to save the trees. He took us to visit two newly planted groves. In both there once stood centuries-old Cellina di Nardò and Ogliarola trees. Those trees have been eradicated and replaced with Leccino and Favolosa (the latter a patented hybrid). Both have shown resistance to Xylella in experimental groves. The young trees are tightly spaced at 2.5 meters to facilitate super high density (SHD) mechanical harvesting of 
the sort used in Spain. Greco sees no other solution and wonders if in another $20-30$ years, by which time the Xylella scourge may have abated, it will be possible to reintroduce some of the traditional cultivars that are currently devastated by the bacteria.

Still farther south, just 20 kilometers from the tip of the Salento, lies the Masseria Gianferrante. Once a family vacation home-I visited decades ago-Yvonne and her husband Antonio turned the masseria (the Puglian term for farm) into a delightful bed and breakfast and also a working organic farm (an agriturismo) starting in 2004. As one might imagine in the Salento, one of the crops they planted was olive: 5 hectares of Leccino, Picholine, Ogliarola, and Cellina di Nardò. They are making monocultivar oils that recently won an award in the Oro d'Italia competition, although as in much of Puglia, the 2018 harvest was poor and they did not bother producing oil at all that year. Following the advice of a local organic vintner, they are meanwhile brewing up a "compost tea" and applying it both to the crown and the base of the trees. They are happy with the results, even though in the months before my arrival both the Cellina di Nardò and the Ogliarola had begun to show signs of drying. Yvonne and Antonio process their olives at the nearby frantoio of Olio Merico in Miggiano.

That frantoio is run by the Lisi siblings. Their ancestors manufactured the usual olio lampante of the Salento and until the 195 os or '6os still operated two frantoi ipogei. Typical of the region these frantoi were built in caverns underground, carved out of soft pietra leccese, the local stone. Frantoi ipogei offered several advantages: olives brought from the surrounding countryside could be easily poured down into storage chimneys below ground level that communicated directly with the crushing area; geothermal heating meanwhile maintained warmer temperatures during the cold winter months when most of the pressing took place and so helped increase yield; and the highpressure wooden screw presses could be built into the sturdy rock walls. On the other hand, the combination of sweat and waste generated by the men and oxen working in these caverns combined with the fumes from fires (used to heat water and to cook with) must have been pretty noxious. Indeed, already in the eighteenth century, a local reformer recommended constructing well-ventilated aboveground frantoi in order to produce better-quality oil.

Marta Lisi spoke with us next to one of the alberi millenari (thousand-year-old trees) included in the family holdings (Figure 7). In a story similar to that of the Paladini, the Lisi family of mostly chemists and pharmacists did not devote a lot of attention to their trees until Marta's father decided that he wanted better quality oil, if only for his own consumption. Breaking with local practices, he began harvesting the olives off the trees (rather than waiting for them to fall) but found that in October-November the local frantoi had not yet started production for the season. So in 2004 he installed a continuous-cycle olive mill in an old straw barn and began making quality oil. The three children have since taken over the business, and in the past decade they have been making better and better, even award-winning, oils with the classic Cellina di Nardò and Ogliarola cultivars. They have fought

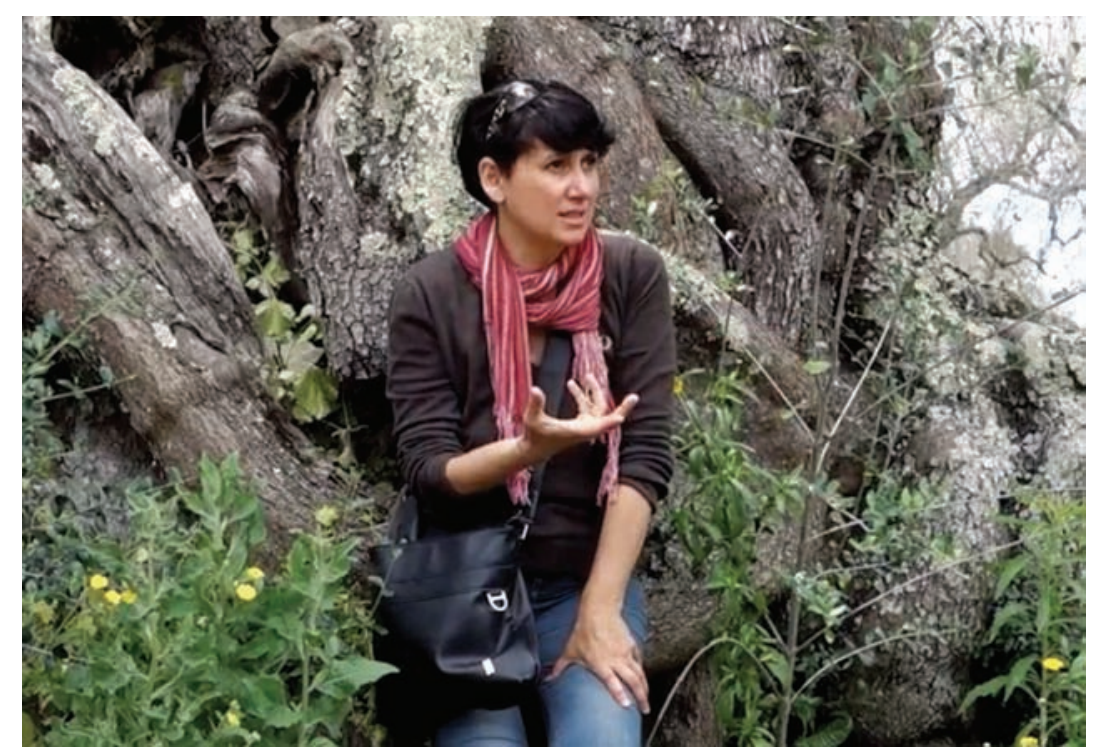

Figure 7: Marta Lisi.

PHOTOGRAPH BY CARL IPSEN () 2019 
hard to overcome the stereotype according to which the salentini only make low-quality olio lampante.

Like some of the others described above, Olio Merico has in recent years converted to organic practices. In response to the threat of Xylella, Marta applied Dentamet (a patented organic compound) to her trees, following promising results obtained by Italian researchers. The Dentamet seemed to be working for Marta, and then several months before our visit, the ancient trees rapidly succumbed to the drying syndrome. Sadly we conducted our interview in front of a magisterial tree whose crown, like those of trees throughout the grove, was entirely scorched. It was a devastating and heart-wrenching scene. The family has other groves that are still productive but their business clearly faces an existential threat. Marta does not advocate a solution like that being implemented in Caprarica, namely the replacement of her trees with super-high-density cultivars, if only because of the heavy use of chemicals and water required. She points out the dramatic impact-economic, social, cultural, and on the burgeoning Salento tourist industry - that the loss of the region's historic trees would bring and is critical of a policy that offers farmers just one option, namely forced use of pesticides to attack the spittlebug combined with eradication and replanting with SHD cultivars. Why not explore other possibilities that might include caring for the diseased trees or supporting farmers who might want to plant other crops? She and fellow growers/producers are questioning if they will be able to continue to make a quality product, or even to make oil at all. Marta remarked ruefully that in the many groves that have been abandoned in the region the typical herbicides have not been applied, and so as an odd collateral benefit they have enjoyed a proliferation of wildflowers and butterflies.

\section{Puglia at a Crossroads}

The situation in Puglia is critical. Current policy calls for eradication of diseased and surrounding trees in the containment and buffer zones plus mowing and the application of pesticides. Experience suggests, though, that efforts to contain or exterminate the spittlebug will prove unsuccessful and so Xylella will likely continue its march northward into the prime oil-growing regions of Bari and beyond. Hopefully best practices there, combined with the relative absence of abandoned groves, will limit its impact, but there is really no way of knowing in advance. As mentioned above, Xylella has already been detected outside Puglia (though due to independent introductions) and so is now a European problem, and one that threatens not just olives. Where Xylella is already present, is the only solution the replacement of diseased trees with resistant (for now anyway) SHD cultivars as in Caprarica and other locales? Various of my interviewees argue that this approach introduces additional toxins into the environment and requires large quantities of water that Puglia, and especially the Salento, does not have. Moreover, they point out, the end result will be a fairly indifferent oil, much like the current industrial oil made in Spain but likely more expensive and so not competitive. Will grafting instead be effective, saving at least the historic trunks and growing Italian cultivars like Leccino and Favolosa? Some growers have already found that extreme pruning does not save the trees, but grafting has always been a tool in the arsenal of the olive grower and can be done successfully. With regard to cultivars, it is interesting to note that the recently approved preliminary document to create an official EU-recognized Olio di Puglia PGI (Protected Geographical Indication) label specifically includes Leccino and Favolosa among the permitted cultivars (but not, as some feared, the classic, mostly Spanish, SHD cultivars like Arbequina and Arbosana) even though they are not traditional Puglian cultivars (EUR-Lex 2019).

Should farmers instead replace olive trees with other cropsone suggestion I have heard is oak trees for truffle cultivationrendering the Puglian countryside unrecognizable? Agriculture is of course not a static venture, and while olives have been grown and oil produced in Puglia for millennia, the relative predominance of this monoculture has varied over time. In the past it was typical to grow vines, vegetables, or grain between widely spaced olive trees, a practice largely abandoned and incompatible with mechanical harvesting. More recently Puglia reigned as Italy's most important producer of tobacco; today there is hardly a tobacco plant to be found. And the balance between olives and wine grapes has always fluctuated there (today Puglia is also Italy's main producer of table grapes). Almonds, meanwhile, are making a comeback. It is nonetheless hard to imagine a Puglia without olives, and a Salento without twisted massive thousand-year-old trunks. But it is also certainly the case that the agricultural balance in the future will be different from what is today, just as today's landscape differs from that of the past.

One approach to the current crisis, although not that generally favored in official circles, is to find a way to live with the disease and care for the trees as best as possible. There is some indication that enriching the soil and pursuing organic best practices provide a degree of protection. And if Dentamet is not the answer, perhaps "compost tea" is a better approach. What I did find in Puglia is that in a world sometimes tainted by fraud and corruption - while I was there a police raid in Cerignola west of Bari uncovered an operation that had been selling chlorophyll-altered seed oil as extra virgin olive oil for years in northern Italy and Germany (Gazzetta del Mezzogiorno 2019)-there are also hundreds 
of honest farmers and producers growing better and better olives, milling them with modern techniques and producing oils of ever higher quality. Those farmers and producers necessarily constitute the front line in the battle against Xylella and it is not clear that they are receiving the kind of support they need. They are also of course the first to suffer. Finally, as I drove north out of the Salento, I could not help but notice a surprising sight: from the top of the scorched crowns of Xylella-afflicted trees, many of them now abandoned, new green growth stretched skyward. As Marta Lisi had remarked to me: "It is hard to kill an olive tree." @

\section{Acknowledgments}

Thanks of course to all the people named above. Not mentioned in the text but equally helpful were Mauro Scarlato (Muraglia); Nino Marmo and Michele Troia in Andria; Nicola Larosa and Carlo de Corato (Covan); Elia and Maria Teresa Pellegrino (Pellegrino 189o); Francesca de Martino (Schinosa); Damiano Napolitano in Andria; Massimo Cassanelli (Galantino); Vincenzo, Claudio, and Francesco Cariello (Bitonto); Emanuele Lamboni (Mimì); Alfredo Marasciulo in Bari; Stefano Caroli (frantoiano and much else in Martina Franca); Cosimo Damiano Guarini in Ostuni; Marcello Palumbo (Sololio, also Ostuni); and Paolo Nutricato (Cantinum Supersanum). In the course of my trip and afterward, I sampled fine oils made by all the producers mentioned. A little online searching will discover them and so how to obtain their products: it is well worth the effort. Thanks also to my colleagues at Indiana University, Stacey Giroux and Kurt Waldman, who joined me for parts of this trip, and Jen Maher made useful editing suggestions. And a special thanks to Marina Foranabaio, andriese in spite of herself, whom I first met at Terra Madre and who facilitated many of the encounters described here.
NOTES

1. For an English-language discussion, see Borunda 2018.

2. For a recent update on Xylella in Europe, see EFSA 2019.

3. For a recent discussion of resistant cultivars, see Sportelli 2019.

\section{REFERENCES}

Borunda, Alejandra. 2018. "Italy's Olive Trees Are Dying: Can They Be Saved?" National Geographic, August 10. www. nationalgeographic.com/science/2018/o8/italy-olive-trees-dyingxylella/.

EFSA 2019. "Xylella Update: Still No Cure, Control Measures Crucial." European Food Safety Authority, May 15. www.efsa. europa.eu/en/press/news/190515-o.

EUR-Lex 2019. "Commission Implementing Regulation (EU) 2019/ 2202 of 16 December 2019 Entering a Name in the Register of Protected Designations of Origin and Protected Geographical Indications Olio di Puglia (PGI) C/2019/9171." https://eur-lex. europa.eu/legal-content/EN/TXT/?qid=1580082925439\& uri=CELEX:32019R2202.

Gazzetta del Mezzogiomo 2019. "Olio di soia spacciato per extravergine: 24 arresti nel Foggiano.” May 14. https://www. lagazzettadelmezzogiorno.it/news/foggia/1140994/olio-di-soiaspacciato-per-extravergine-24-misure-cautelari-nel-foggiano.html

Italia olivicola. 2019. Proposta per un piano straordinario di riconversione e di ristrutturazione degli oliveti salentini. www. italiaolivicola.it/wp-content/uploads/2019/o2/Studio-piano-xylella. pdf.

Scagliarini, Massimiliano. 2019. "Xylella, l'Ue cambierà le misure di emergenze." La Gazzetta del Mezzogiorno, November 3. www. lagazzettadelmezzogiorno.it/news/home/1184219/xylella-l-uecambiera-le-misure-di-emergenze-ridotta-l-area-di-taglio.html.

Sportelli, Giuseppe Francesco. 2019. "Xylella, dal progetto POnTE sei cultivar con caratteri di resistenza/tolleranza." Terra e vita, November 2. https:/terraevita.edagricole.it/olivicoltura/xylellasei-cultivar-hanno-dimostrato-nel-progetto-ponte-promettenticaratteri-di-resistenza-tolleranza/.

Strona, Giovanni, Corrie Jacobien Carstens, and Pieter S. A. Beck. 2017. "Network Analysis Reveals Why Xylella Fastidiosa Will Persist in Europe." Scientific Reports 7: 71. www.ncbi.nlm.nih. gov/pmc/articles/PMC5428346/. 